\title{
THE EFFECT OF ONION (Allium sativum) EXTRACT TO TREAT TILAPIA FRY (Oreochromis niloticus) WITH BACTERIAL INFECTED Aeromonas hydrophila
}

\author{
Ani Lestari ${ }^{1}{ }^{*}$, Nurliah ${ }^{1}$, Baiq Hilda Astriana ${ }^{1}$ \\ ${ }^{1}$ Aquaculture Study Program, Faculty of Agriculture, Mataram University, Pendidikan St 37, \\ Mataram, Nusa Tenggara Barat, Indonesia
}

*Correspondence : lestariani426@gmail.com

Received : 2021-05-21

Accepted : 2021-06-23

Keywords :

garlic, tilapia, Aeromonas

hydrophila bacteria.

\begin{abstract}
Research on the effect of garlic extract (allium sativum) to treat tilapia (oreochromis niloticus) seeds which are infected with aeromonas hydrophila bacteria. This research was conducted for 14 days from 18 December to 31 December 2019 which took place at the Wet Laboratory of the Aquaculture Study Program, Mataram University, West Nusa Tenggara (NTB). This study used a completely randomized design (CRD) with an experimental method consisting of 5 treatments and 3 replications. The container used in this study was a 15 liter jar with a volume of 10 liters. The containers used are 15 units, where in treatment one (P1) using without soaking garlic extract and without being infected with Aeromonas hydrophila bacteria, treatment two (P2) without soaking garlic extract and being infected with Aeromonas hydrophila bacteria, (P3) using soaking onion extract white with a concentration of $1 \%$ and infected with Aeromonas hydrophila bacteria, (P4) using garlic extract immersion with a concentration of $1.5 \%$ and infected with Aeromonas hydrophila bacteria, (P5) using garlic extract immersion with a concentration of $2 \%$ and infected with Aeromonas hydrophila bacteria. The parameters observed during the study included survival rate (SR), relative percent survival (RPS), observation of clinical symptoms, and water quality. The results showed that giving garlic extract with different concentrations had a significantly different effect on survival rates and relative percent survival (RPS).
\end{abstract}

\section{INTRODUCTION}

Tilapia (Oreochromis niloticus) in Indonesia is one of the freshwater fish that has high economic value and is an important commodity in the world's freshwater fish business. According to production data from the Directorate General of Aquaculture (DJBP) KKP (2017), tilapia production in Indonesia since 2013 has increased from 914.78 thousand tons to 999.64 thousand tons in 2014, then in 2015 tilapia production reached 1.084 million tons. with an export value of 14,681 tons, but the economic value of exports decreased to 11,978 tons in 2016.

One cause of declining fish production is an attack form of the disease, which is a serious problem for fish farmers because it can cause huge losses. $\mathrm{S}$ moans disease can also 
Journal of Fish Health Vol. 1 (1) - Juni 2021

Lestari et al. (2021)

https://doi.org/10.29303/jfh.v1i1.163

lead to a decrease in the quality of the fish, so economically result in a decrease in selling prices of fish (Mariyono and Agus, 2005).

MAS (Motile Aeromonas Septicemia) is a disease caused by A. hydrophila bacteria that attacks tilapia and other freshwater fish species (Giyati, 2000). This MAS disease has clinical symptoms, namely reduced fish appetite, bleeding in the gills, there are wounds on the body of the fish, scales are detached, the tail fin is damaged, the stomach is enlarged due to fluid, as well as swelling of the lymph tissue, liver and kidneys and can cause swelling in the spleen tissue, liver and kidneys. mortality rate is $80 \%$ (Tantu et al., 2013). The bacterium $A$. hydrophila is one of the bacteria that attacks fish from the seed stage to adulthood. The seed stage is a death-prone phase, because at this stage the fish's immune system is not fully developed (Hanif et al., 2004).

The use of antibiotics and chemicals in an effort to prevent and treat $A$. hydrophila bacterial infection can continuously damage the aquatic environment and poison fish and result in bacterial resistance to antibiotics, so that the use of antibiotics becomes ineffective (Irawan et al., 2003). Treatment using herbal medicine is still lacking, some ingredients that are often used include noni leaves, ketapang leaves and moringa leaves. One of the ingredients that can be used is garlic (Allium sativum) which is environmentally friendly and inexpensive. In addition, garlic contains Allicin which is an active substance that is able to kill bacteria and has anti-inflammatory power. The use of garlic as an herbal ingredient in aquaculture activities is able to cure fish infected with bacteria into one of the considerations for its use as an antibacterial agent as in previous studies, namely the use of garlic extract to treat Siamese catfish (Pangasius hypophtalmus) seeds infected with Aeromonas hydrophyla bacteria. (Muslim, 2009) and administration of garlic extract with different concentrations on the survival of tilapia infected with Streptococcus ineae (Zahraturrahmah, 2018). This study aims to determine the effect of garlic extract ( Allium sativum ) on A. hydrophila bacteria that attack tilapia (Oreochromis niloticus) fry .

Based on the above, it is necessary to study the use of extracts of garlic as a natural antibiotic and antibacterial or expected to be an alternative to natural substances in the treatment of diseases caused by bacteria $A$. hydroph i la on tilapia fry. This study aimed to determine the effect of garlic extract white (Allium sativum) against bacterial disease in tilapia fish (Oreochromis niloticus) caused by the bacterium A. hydrophi la .

\section{METHODOLOGY}

Materials and tools

The materials used in this study were tilapia, garlic extract, isolate aeromonas hydrophila, aquades, artificial feed, and fresh water. The tools used in this study were jars, scales, aerators, seser, petri dishes, microscopes, small buckets, cameras, tissue, DO meters, thermometers, pH meters, test tubes, Erlenmeyer, oasis needle, autoclave, spatula, magnetic strirer, hotplate, refrigerator, blender, laminar, and incubator.

Research methods

The test used was tilapia seeds, tilapia seeds used were seeds measuring $4-5 \mathrm{~cm}$. Maintenance is carried out for 14 days in a 15 liter animal jar with a water volume of 10 liters. This study used RAL (Completely Randomized Design) with experimental methods with 5 treatments and 3 replications, namely (P1) using no soaking garlic extract and without being infected with Aeromonas hydrophila bacteria (P2) without soaking garlic extract and 
Journal of Fish Health Vol. 1 (1) - Juni 2021

Lestari et al. (2021)

https://doi.org/10.29303/jfh.v1i1.163

infected with Aeromonas hydrophila bacteria, (P3 ) using soaking garlic extract with a concentration of $1 \%$ and infected with Aeromonas hydrophila bacteria, treatment (P4) using soaking garlic extract with a concentration of $1.5 \%$ and infected with Aeromonas hydrophila bacteria, treatment (P5) using soaking garlic extract with a concentration of $2 \%$ and infected with Aeromonas hydrophila bacteria.

Data analysis

Data that has been collected during the research process was analyzed using ANOVA (analysis of variance) at a 95\% confidence level through the SPSS program and Duncan's further test was carried out to determine the best treatment.

\section{RESULT}

Survival Rate (SR)

The results of observing the survival rate of tilapia fry treated with garlic extract during rearing can be seen in figure 1 .

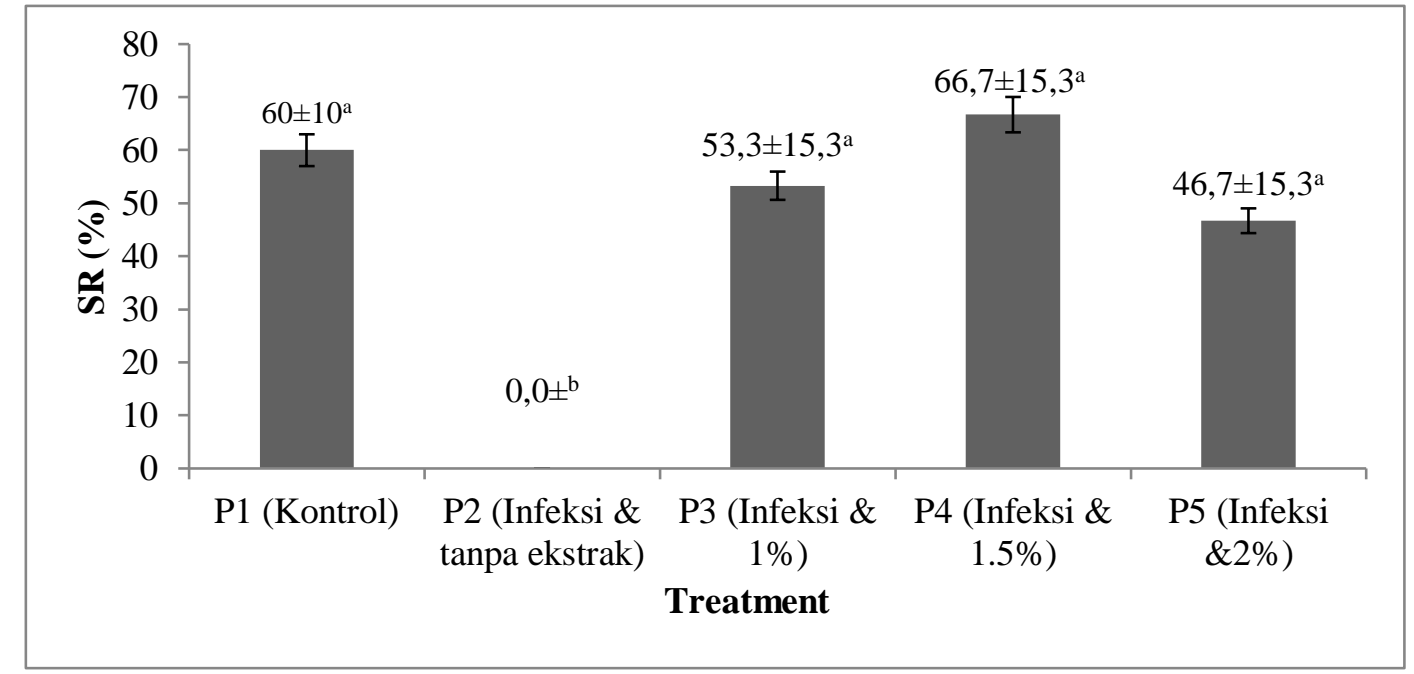

Figure 1. Survival Rate

The survival rate of tilapia in each treatment was given soaking garlic extracts with varying concentrations of mem iliki values ranging from $0.0 \%$ to $66.7 \%$. In this study, administration soaking garlic extract with a concentration of $1.5 \%$ (P4) gave the highest score of $66,7 \%$ followed successively by the administration without soaking the garlic extract and without penginf eksian bacteria (P1) with a value of $60 \%$, garlic extract with a concentration of $1 \%$ and bacterial infection (P3) with a value of $53.3 \%$, garlic extract with a concentration of $2 \%$ and bacterial infection (P5) with a value of $46.7 \%$ and the lowest value was in the treatment without soaking garlic extract and bacterial infection (P2) with a value of $0.0 \%$.

Based on analysis of variance showed that soaking garlic extract with different concentrations gave a significantly different effect or significant $(p<0.05)$ on the survival rate of tilapia so that Duncan's further test was carried out to determine the best treatment. Further test results showed that $\mathrm{P} 4$ was not significantly different from $\mathrm{P} 1$, P3 and P5, but significantly different from P2.

Relative Percent Survival (RPS)

The results of observations of RPS of tilapia seeds that were given treatment in the form of garlic extract during maintenance can be seen in figure 2 . 
Journal of Fish Health Vol. 1 (1) - Juni 2021

Lestari et al. (2021)

https://doi.org/10.29303/jfh.v1i1.163

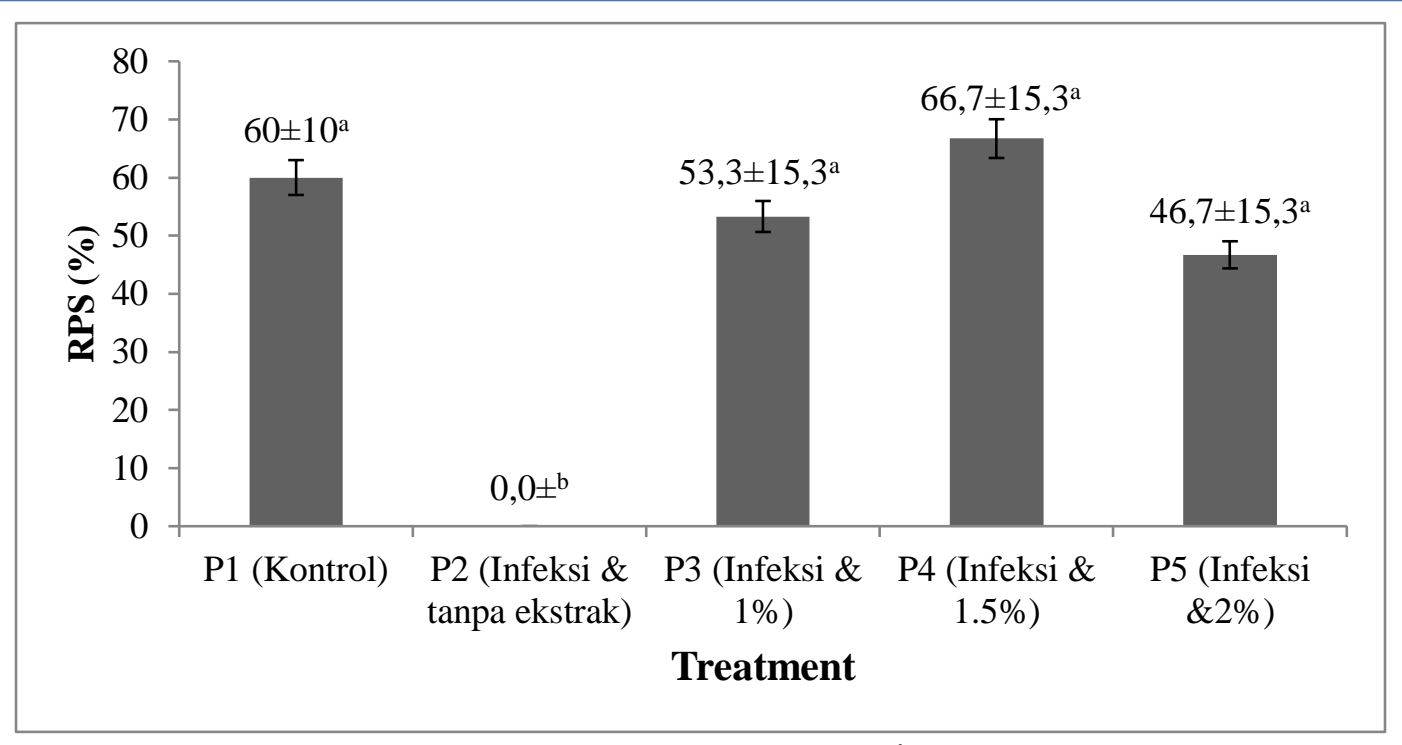

Figure 2. Relative Percent Survival (RPS

The relative percent survival (RPS) of tilapia seeds in each treatment was given garlic extract immersion with different concentrations ranging from $0.0 \%$ to $66.7 \%$. In this study, the administration of soaking garlic extract with a concentration of $1.5 \%$ (P4) gave the highest value of $66.7 \%$ followed by administration without soaking garlic extract and without bacterial infection (P1) with a value of $60 \%$, garlic extract with a concentration of $1 \%$ and bacterial infection (P3) with a value of $53.3 \%$, garlic extract with a concentration of $2 \%$ and bacterial infection (P5) with a value of $46.7 \%$ and the lowest value was found in the treatment without extract soaking garlic and bacterial infection (P2) with a value of $0.0 \%$.

Based on the analysis of variance showed that soaking the garlic extract with a concentration of the different effect of different tangible or significant $(p<0.05)$ to the level to succeeding cured (Relative Percent Survival) seed tilapia so do a further test Duncan to determine the best treatment. Further test results showed that $\mathrm{P} 4$ was not significantly different from P1, P3 and P5, but significantly different from P2.

Clinical Symptoms

During Infection

Clinical symptoms observed during infection were known that in general the symptoms that occurred in fish were fish began to swim around, decreased appetite, loss of swimming balance, some fish began to limp. Fish began to become infected with the characteristics of swimming in circles, swimming to the surface, fish fins begin to fall off, scales detach, sores or ulcers and bleeding in the operculum. This is also in accordance with the results of the study Figures (2001) which found that fish attacked by $A$. hy drophila bacteria showed clinical symptoms such as damage to the tail fin, pelvic fins, and pectoral fins, then wounds (ulcers), flatulence and if the pelvic fins are not treated immediately. If treated, the bacteria will spread in the blood vessels and continue to the organs in the abdomen, causing swelling (drops) and causing yellow fluid. Furthermore, the fish died on day 4 after infection. 
Journal of Fish Health Vol. 1 (1) - Juni 2021

Lestari et al. (2021)

https://doi.org/10.29303/jfh.v1i1.163
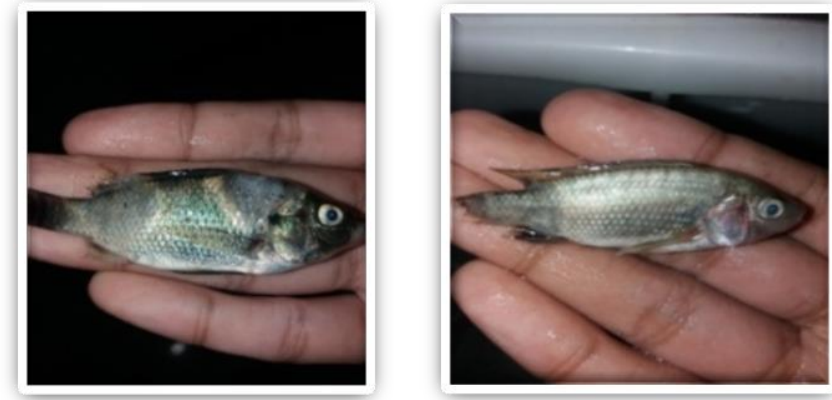

Figure 3. Scales and caudal fin detached

During Treatment and During Maintenance

The symptoms of tilapia observed during treatment and during maintenance can be seen in table 1 below :

Table 1 . Pre-infection and post-treatment symptoms

\begin{tabular}{|c|c|c|c|}
\hline Treatment & Post Infection & Post Treatment & Information \\
\hline $\begin{array}{l}\text { P1 (Without } \\
\text { Infecting }\end{array}$ & & & $\begin{array}{l}\text { On the day of stocking the } \\
\text { fish were still in good }\end{array}$ \\
\hline $\begin{array}{l}\text { Bacteria and } \\
\text { Extracts }\end{array}$ & & & $\begin{array}{l}\text { health and normal. Then } \\
\text { during maintenance there }\end{array}$ \\
\hline
\end{tabular}

\section{P2 (Bacteria and No Extract}
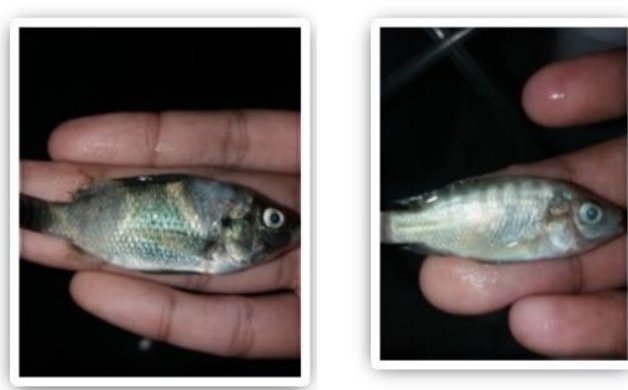

Extracts

Bacteria P4 and 1, $5 \%$ )
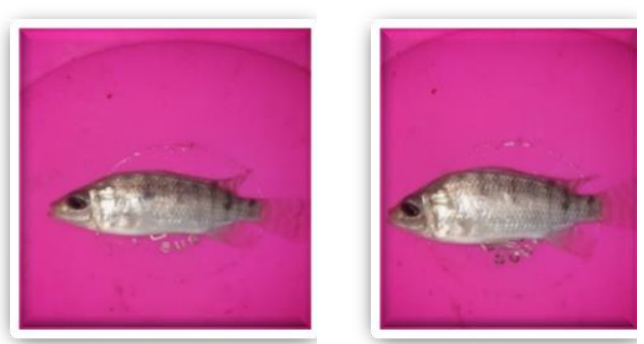

After 3 days of rearing the fish experienced symptoms such as scale loss, ulcers, caudal and ventral fins detached

During the 3 to 4 day maintenance period after infection, the fish experience symptoms such as the tail fin falling out and there are ulcers. After adding the extract into the rearing media, the fish began to show agile fish movements and there were no ulcers. 
Journal of Fish Health Vol. 1 (1) - Juni 2021

Lestari et al. (2021)

https://doi.org/10.29303/jfh.v1i1.163

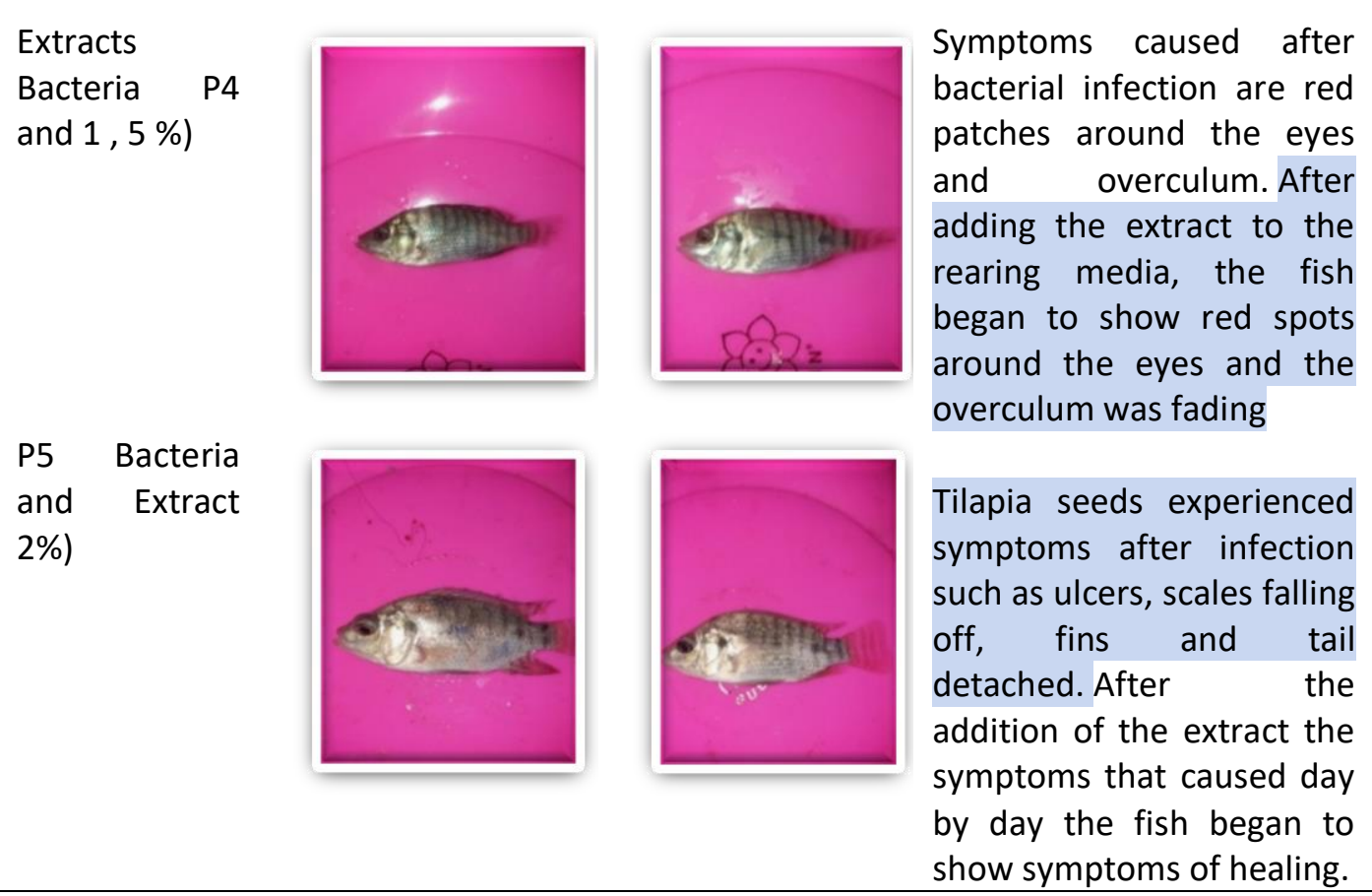

Water quality

The water quality parameters observed were temperature, $\mathrm{pH}$, and DO. Water quality from the beginning of infection, treatment and maintenance was no problem for fish, and water quality was normal. Water quality parameters can be seen in table 2 below:

Table 2. Water quality measurement data

\begin{tabular}{ccccccc}
\hline Treatment & \multicolumn{3}{c}{ first week } & \multicolumn{3}{c}{ second week } \\
& $\begin{array}{c}\text { DO } \\
(\mathrm{ppm})\end{array}$ & $\mathrm{pH}$ & $\begin{array}{c}\text { Temperature } \\
\left({ }^{\circ} \mathrm{C}\right)\end{array}$ & $\begin{array}{c}\mathrm{DO} \\
(\mathrm{ppm})\end{array}$ & $\mathrm{pH}$ & $\begin{array}{c}\text { Temperature } \\
\left({ }^{\circ} \mathrm{C}\right)\end{array}$ \\
\hline P1 & $5,1-5,3$ & $7,2-7,3$ & $28,1-28,2$ & $5,1-5,2$ & $7,2-7,4$ & $28,3-28,4$ \\
P2 & $4,2-5,2$ & $7,1-7,2$ & $28,1-28,2$ & $5,1-5,5$ & $7,2-7,5$ & $28,3-28,6$ \\
P3 & $5,0-5,1$ & $7,2-7,3$ & $28,2-28,4$ & $5,0-5,2$ & $7,2-7,3$ & $28,2-28,4$ \\
P4 & $5,1-5,3$ & $7,2-7,3$ & $28,1-28,2$ & $5,0-5,2$ & $7,2-7,3$ & $28,3-28,4$ \\
P5 & $4,4-5,0$ & $7,0-7,5$ & $28,1-28,3$ & $4,3-4,7$ & $7,0-7,4$ & $28,1-28,3$ \\
Reference & $3-6 \mathrm{ppm}$ & $5-9$ & $25-30^{\circ} \mathrm{C}$ & $3-6 \mathrm{ppm}$ & $5-9$ & $25-30^{\circ} \mathrm{C}$ \\
& Gufran & Khairuman & Rukmana & Gufran & Khairuman & Rukmana \\
& $(2010)$ & $(2013)$ & $(2008)$ & $(2010)$ & $(2013)$ & $(2008)$ \\
\hline
\end{tabular}

\section{DISCUSSION}

The high survival rate of tilapia fry at P4 (1.5\%) is thought to be due to the $1.5 \%$ concentration of garlic extract containing the compound Alicin which functions as an antibacterial so that it can increase the survival rate of tilapia fry. This is in accordance with the statement of Wibowo (1989). in Muslim et al., (2009), explained that garlic ( A. sativum ) has an active compound, namely Allicin where Allicin is an active substance that can kill bacteria and can cleanse the blood of toxins produced by bacteria. According to Handayani \& Siswanto (2019), it also explained that the use of garlic extract to combat $A$. hydrophila bacteria that attacks tilapia seeds (Oreochromis niloticus) has a $66.67 \%-90 \%$ survival rate of tilapia seeds. Garlic can be used to control pathogens, increase immune responses, and have a positive effect on the survival rate of fish (Aniputri et.al, 2014). 
Journal of Fish Health Vol. 1 (1) - Juni 2021

Lestari et al. (2021)

https://doi.org/10.29303/jfh.v1i1.163

According to Fatimah (1992) in Murjani (2011) that fish survival is highly dependent on adaptability. fish on food and the environment, fish health status, stocking density, and sufficient water quality to support growth.

Lower survival rate of tilapia fish in P2 treatment because it is allegedly not be giving garlic extract will however remain infected with the bacterium that causes tilapia fish susceptible to death due to lack of antibacterial. This is indicated by the condition of the fish having ulcers on the fish's body, the scales are detached, the tail fin is flaky and the fish suffers sudden death. This is in accordance with the statement of Figures (2001), which states that fish infected with $A$. hydrophila bacteria show clinical symptoms such as damage to the tail fin, pelvic fins, and pectoral fins, then wounds (ulcers), flatulence and if the pelvic fins are not treated immediately. , bacteria will spread in the blood vessels and continue to the organs in the abdomen, causing swelling (drops) and causing a yellow liquid.

According to Muslimet al, (2009) that the death of fish attacked by $A$. hydrophila bacteria shows clinical symptoms such as fish not wanting to eat so that the body's resistance decreases so that the ability to swim of fish decreases where fish are more often on the surface of the water, red spots are found on the surface of the water. on the surface of the body is getting worse, causing damage to the fins where the tail fin is thin, the fish's stomach is getting bloated and the eyes are sunken which then causes the fish to die.

Meanwhile, the P5 treatment had an unfavorable survival value with a value of $<50 \%$. This is in accordance with the statement of Husen (1985) in Mulyani (2014) that the survival rate tergolong $50 \%$ is classified as good, survival is $30-50 \%$ moderate and less than $30 \%$ is not good. This is presumably because the high concentration of garlic extract given to P5 resulted in stress and death of fish. This was shown during the study on P5 tilapia seeds had abnormal movements and were always on the surface of the rearing media and had the most mortality compared to other treatments soaked using garlic extract. This is in accordance with Anderson's (1974) statement in Lukistyowati et al (2007) which states that if there are factors that interfere with fish, be it parasites, chemicals or physical stimuli that trigger stress in fish. In addition, the presence of fish jumping up and down uncontrollably also indicates that the fish feel uncomfortable with their environment.

The high rate of cure tilapia fish on a P4 with konsentrasi1 , $5 \%$ as much as $66.7 \%$ showed the highest results. This is because the number concentration of $1,5 \%$ is the best treatment and was able to heal tilapia fish infected with the bacteria A.hydrophila. Giving garlic extract can increase the fish's body resistance to fish infected with $A$. hydrophila bacteria. This is in accordance with the statement of Syamsiah and Tajudin (2003), giving garlic extract for the treatment of $A$. hydrophila bacteria in catfish can increase survival, this is presumably due to the influence of the active substances contained in garlic, namely allicin and scordinin where allicin has the ability to kill The bacteria in this case is the bacteria $A$. hydrophila. Allicin contained in garlic can also kill gram-positive bacteria and gram-negative bacteria and serves to increase the body's resistance to prevent the entry of germs.

The low success rate of recovering tilapia fry at $\mathrm{P} 2$ with a value of $0.0 \%$ was due to the treatment that the fish were infected with bacteria and without garlic extract so that all tilapia seeds died and at P5 with a value of $46.7 \%$ it was not good with a value of $<50 \%$. on the success rate of fish recovery. This is in accordance with the statement of Ellis (1988) in Lukisyowati (2004) which states that the success rate to obtain an effective relative survival when the RPS value is $50 \%$. This is also in accordance with the opinion of Masdewati (2005) in his research that the RPS value was obtained at a concentration of $6 \mathrm{ml} / \mathrm{l}$ by $52 \%$. 
Journal of Fish Health Vol. 1 (1) - Juni 2021

Lestari et al. (2021)

https://doi.org/10.29303/jfh.v1i1.163

At P5 with a concentration of $2 \%$ with a low recovery rate of tilapia fry due to the high concentration given to tilapia fry, causing tilapia fry to experience clinical symptoms of sluggish fish movement, swimming around, and always swimming to the surface of the water. This is because the administration of garlic extract with a concentration that is too high is less effective and can kill fish seeds. This is in accordance with the statement of Pelezar and Chan (1986) in Sari et al, (2014) who argue that the higher the antimicrobial concentration used, the faster it will kill bacteria, but the use of too high a concentration is less effective in treatment because it can kill fish and bacteria. It is also less economical to use. The excessive soaking of the garlic extract causes the fish to not survive, because the fish when soaked in a weak state are infected with $A$. hydrophila bacteria so that this condition is exacerbated by stress.

Symptoms of healthy fish after being treated for 30 minutes and kept for 14 days can be seen that the observation of clinical symptoms in fish after being treated with garlic extract on the first day of fish has not shown any change, this is because the garlic extract has not worked in the fish's body so that the resulting mortality occurs on the first day because the bacteria in the fish's body are still working. On day 4 to day 14 fish in P4 (concentration of $1,5 \%$ ), followed by P3 (concentration 1\%) and P5 (concentration 2\%) showed symptoms of fish fade away, its body color brilliant than fish in treatment P2 (Bacterial infection and without the addition of extract), the movement began to be agile and the fish began to eat. This is stated by (Lukistiowati, 2004 in Muslim et al. 2009) that catfish given garlic extract can increase the resistance of the fish, so that the movement becomes agile and the color is brilliant.

Water quality parameters during infection, treatment, and maintenance were still at optimal levels and could still be tolerated by tilapia fry. This can be seen in table 5 . That is for the temperature parameters in the measurement in the first week in treatment $\mathrm{P} 1$ ranging from $28.1-28.2{ }^{\circ} \mathrm{C}$, in the second week $28.3-28.4{ }^{\circ} \mathrm{C}$ and not much different in treatment $\mathrm{P} 2$, P3, P4 and P5. For the measurement of DO during the first week in all treatments ranged from 4,4 to $5.3 \mathrm{ppm}$ while in the second week of measurement ranges between $4.3-5,2$ $\mathrm{ppm}$. And for the measurement of $\mathrm{pH}$ in all treatments during the first week ranged from 7 , $1-7.3$ and the second week ranged between 7.2-7.5. The infection of $A$. hydropila bacteria in tilapia during the maintenance of water quality values in this study was still at a normal level so that it could support the survival rate of tilapia. This is in accordance with the literature obtained, namely the temperature of $25-30{ }^{\circ} \mathrm{C}$ (Rukmana, 2008), pH 5-9 (Khairuman, 2013), and DO 3-6 ppm (Gufran, 2010).

\section{CONCLUSION}

Based on the results of this study concluded that $p$ enambahan garlic extract may increase survival rate (SR) and relative percent survival (RPS) seed tilapia tested challenged with bacteria $A$. hydrophila.

\section{ACKNOWLEDGMENT}

In this opportunity, the researcher would like to express their gratitude to the University of Mataram for facilitating this research activity. 


\section{REFERENCES}

Aniputri, DF Hutabarat, J. \& Subandiyno2014. The Effect of Garlic Extract (Allium sativum) on the Prevention Level of Aeromonas hydrophyla Bacterial Infection and Life Graduation of Tilapia (Oreocromis niloticus). Aquaculture Study Program, Department of Fisheries, Faculty of Fisheries and Marine Sciences. Diponegoro University.

Angka, SL 2001. Sambiloto Can Protect Dumbo Catfish from Motile Aeromonas Septicemia (MAS) . ( Online). CyberNew Daily Suara Merdeka. Semarang. Retrieved April 14, 2005.

Arifianto, E. and Liviawaty, E. 1992. Pest and Disease Control of Canisius Fish, Jakarta.

Arifin, YM 2016. Growth and Survival Rate of Tilapia (Oreochromis sp) Red Strain and Black Strain Raised on Salinity Media. Scientific Journal of Batanghari University Jambi Vol.16 No.1

Bahar. IS 2017. Specific Immune Response of Carp (Cyprinus carpio) Larvae Through Maternal Immunity Given Inactivated Whole Cell Aeromonas salmonicida Vaccine. [ Thesis]. Faculty of Agriculture. Lampung University. Bandar Lampung

Bakht J, Tayyab M, Ali H, Islam A \& Shafi M, 2011. Effect of different solvent extracted sample of Allium sativum (Linn) on bacteria and fungi. African Journal of Biotechnology .Vol.10 (4). pp. 666-69.

Benkeblia N. 2004. Antimicrobal activity of essential oil extracts of various onion ( Allium cepa) and garlic ( Allium sativum ). Lebensm .- wiss. u - Technol . Vol37. PP: 263-268.

Butt MS, M . T. Sultan, and J. Iqbal. 2009. Garlic: Nature's Protection Against Physiological Threats. Critical Reviews in Food Science and Nutrition , 49 (6) : 538-51

Directorate General of Cultivation (DJBP) KKP, 2017. About Tilapia Production in Indonesia.

Deresse, D. 2010. Antibacterial Effect of Garlic (Allium sativum) on Staphyloccus aureus: An in vitro study. Asian journal of Medical Sciences. 2(2) : 62-65.

Dusica, SD. 2011. Garlic . Retrieved January 10, 2018. Available from: https://umm.ed/health/medical/almated/garlic .

Firnanda, R., Sugito, Fakhrurrazi and DVS Ambarwati. 2013. Isolation of Aeromonas hydrophila on tilapia (Oreochromis niloticus) scales fed with jaloh leaf flour (Salix tetrasperma Ro bx). Journal of Veterinary Medicine 7(1): 22-24 .

Ghufran.2010. Tilapia Cultivation in Tarpaulin Ponds . Lily Publisher. Yogyakarta

Ginting, R. 2018. Anti-Microbial Effectiveness Of Garlic Extract (Allium sativum) Against Bacterial Growth That Causes Chronic Suppurative Otitis Media In vitro. Faculty of Medicine, University of North Sumatra. Field.

Giyarti D. 2000. Effectiveness of Guava Leaf Extract (Psidium guajava L.), Sambiloto (Andrographis paniculata [Burm. f.] Nees) and Betel (Piperbetle L.) against Aeromonas hydrophila Bacterial Infection in Catfish (Pangasius hypophthalmus).[ Thesis] .Faculty of Fisheries and Marine Sciences, Bogor Agricultural University, Bogor.

Handayani and Siswanto.2019. Use of Garlic Extract to Overcome Aeromonas hydrophila Bacteria that Attack Tilapia (Oreochromis niloticus) Seeds. Aquaculture Study Program. Darwan Ali University.

Hanif A, Bakopoulos V, Dimitriadis GJ. 2004. Maternal transfer of humoral specific and nonspecific immune parameters to sea bream Sparus auratalarvae. Fish and Shellfish Immunology 17: 411-435.

Hernawan, UE, and AD Setyawan. 2003. Review: Garlic (Allium sativumL.) Organosulfur Compounds and Their Biological Activities. Biopharmaceutical, 1(2):65-76 
Journal of Fish Health Vol. 1 (1) - Juni 2021

Lestari et al. (2021)

https://doi.org/10.29303/jfh.v1i1.163

Holt, JG, NR Krieg., PHA Sneath., JT Staley and S.T. Williams. 1994. Bergey's manual of Indonesia in "food quality; a challenge for north and south", pp. 265-274.A

Irawan GDE., Winarno K., Susilowati A. 2003. Effect of neem leaf extract (Azadirachta indica A. Juss) on reducing mortality of African catfish (Clariasgariepinus) due to Aeromonas hydrophila infection . Enviro3 (1): 28-35.

Kabata, Z. 1985. Parasites and Diseases of Fish Cultured in Tropics. Taylor and Francisco Ltd. London

Khairuman. 2013. Cultivation of Tilapia . AgroMedia Library

Kordi KM Gufran H. 2010. A Complete Guide to Buying Freshwater Fish in Tarpaulin Ponds . Lily Publisher. Yogyakarta

Kulsum. HS, 2014. Antifunctional Activity of Garlic and Black Garlic Extracts of Lumbu Hijau Varieties with Different Extraction Methods Against the Growth of Candida albicans. Publication manuscript.-

Laili, U. (2007). Effect of Giving Temulawak Extract (Curcuma xantharrhiza roxb) on Prevalence and Survival of Carp (Cyprinus carpio) infected with Aeromonas hydrophia bacteria. Thesis. Bachelor of Science Program at the State Islamic University of Malang.

Londhe VP, Gavasane AT, Nipate SS, Bandawane D \& Chaudhari PD. 2011. Role of Garlic (Allium sativum) in Various Diseases : an Overview. Journal of Pharmaceutical Research and Opinion. 1: 4. Pp. 129-134.

Lubis, YPP, Yunasfi and R. Leidonald. 2014. Types of bacteria in catfish wounds. Journal of Aquacotamarine. 2(1): 66-77

Lukistyowati, I. 2004. Utilization of Garlic Extract (Allium sativum) for the Treatment of Bacteria (Aeromonas hydrophylla) . Research journal. Riau University. Pekanbaru.

Lukistyowati, I. 2017. Garlic Extract (Allium sativum) To Prevent and Treat Motile Aeromnas Septicemia (MAS) in Carp (Cyprinus carpio).Journal of Fisheries (J. Fish. Sci.) x (1):11-19.

Mariyono, Agus S. 2005. Techniques for the prevention and treatment of red spot disease in freshwater fish caused by the bacterium Aeromonas hydrophila. Agricultural Engineering Bulletin 7(1)

Masdewati. 2005. Potential of Garlic (A. sativum) to Increase Body Resistance of Carp (Cyprinus carpio L) Against Aeromonas hydrophylla Bacteria. Thesis of the Faculty of Fisheries and Marine Affairs. Riau University .

Mikaili P, Maadirad S \& Moloudizargari M. 2013. Therapeutic uses and pharmacological properties of Garlic, Shallot and their Biological Active Compounds. Iran $j$ Basic Med. 16 (10). PP: 1031-48.

Mulqan, M., SA Rahimi, I. Dewiyanti. 2017. Growth and Survival of Agile Tilapia (Oreochromis Niloticus) Seeds in Aquaponic Systems with Different Plant Types. Scientific Journal of Marine and Fisheries Students Unsyiah. Vol 2, No 1:183-193.

Mulyani, YS, Yulisman, \& Fitrani, M. (2014). Growth and Feed Efficiency of Tilapia (Oreochromis niloticus) Fasted Periodically. Indonesian Journal of Rawa Aquaculture, 2(1), 1-12.Na, J., Ri, F \& He, D. 2015. Feeding Frequency On Growth And Feed Conversion Of Clarias gariepinus (Buchell, 1822) Fingelings. International Journal of Fisheries and Aquatic Studies, vol. 3, no. 1 , pp . 353-356.

Murjani, A. 2001. Cultivation of Several Varieties of Swamp Sepat Fish (Trichogaster trichopterus Pall) with Commercial Feeding. Journal of Fish Scientiae. 1( 2):214-233. 
Journal of Fish Health Vol. 1 (1) - Juni 2021

Lestari et al. (2021)

https://doi.org/10.29303/jfh.v1i1.163

Muslim. Hotly, MP, Widjayanti, H. 2009. Use of Garlic Extract (Allium sativum) to Treat Siamese Catfish (Pangasius hypophthalmus) infected with Aeromonas hydrophilla bacteria . Indonesian Journal of Aquaculture, 8(1):91-100.

Prasanoto D, Riyanti Eriska \& Gartika Meirina. 2017. Antioxidant Activity Test of Garlic Extract ( Allium sativum ). Odonto Dental Journal Volume 4 . Number 2.

Rukmana.2008. Tilapia Cultivation and Agribusiness Prospects.

Saparianto C \& Susiana R. 2011. Tips for Successful Tilapia Cultivation. Lily Publisher. Yogyakarta.

Sarjito, SB Prayitno., AHC, Haditomo. 2013. Introduction to Fish Parasites and Diseases Book. UPT UNDIP Press : Semarang. 1-95.

Sari, RD Prayitno, BS Sarjito. 2014. The Effect of Soaking Garlic Extract (Alium sativum) on Life Graduation and Kidney Histology of Catfish (Clarias gariepinus) Infected with Edwwardsiella tarda Bacteria. Aquaculture Study Program. Faculty of Fisheries and Marine Science. Diponegoro University.

Santoso, HB 2000. Garlic edition 12. Kanisius, Yogyakarta.

Soetomo, HMA 1989. Dumbo Catfish Cultivation Techniques. New Light. Bandung. 109 pages

Syamsiah, IS, and Tajudin., 2003. Benefits and Benefits of Garlic. Jakarta: Agromedia Pustaka.

Syifa, Net al., 2013. Effectiveness Test of Garlic Extract (Allium sativum Linn.) As Antibacterial in Fresh Milkfish (Chanos chanos Forsk.) . Biology Department. Faculty of Mathematics and Natural Sciences. Semarang State University. Indonesia.

Tantu W, Tumbol RA, Longdong SNJ. 2013. Detection of the presence of bacteria Aeromonas sp. on tilapia cultured in the floating net cages of Lake Tondano.Journal of Aquaculture. 1: $74-80$.

Utami. DT, Prayitno. SB, Hastuti. S., Santika.A., 2013. Description of Hematological Parameters in Tilapia (Oreochromis Niloticus) Given Streptococcus Iniae DNA Vaccine With Different Doses . Journal of Aquaculture Management and Technology Volume 2, Number 4.-

Widiastuti, IM 2009. Growth and Survival Rate of Carp (Cyprinus carpio) Raised in Controlled Containers with Different Stocking Density. Central Sulawesi Research and Development Media.2(2) : 126-130. ISSN : 1979-5971.

Zahraturrahmah, M. 2018. Provision of Garlic Extract with Different Concentrations on the Survival of Tilapia Fish Infected with Streptococcus ineae. Aquaculture Study Program. Mataram University. 